\title{
EMPOWERMENT VISIONARY LEADERSHIP AND JOB SATISFACTION TO IMPROVE TEACHER CREATIVITY
}

\author{
Peni Apriyani $^{a)}$, Entis Sutisna ${ }^{a)}$, Henny Suharyati ${ }^{a *}$ \\ ${ }^{a)}$ Pakuan University, Bogor, Indonesia \\ ${ }^{*}$ Corresponding Author: henny.suharyati@unpak.ac.id
}

Article history: received 17 July 2019; revised 26 July 2019; accepted 26 August 2019

\begin{abstract}
This study examines the improvement of teacher creativity which is driven by the visionary leadership strength of the principal and teacher job satisfaction. The survey method with the correlational approach was used in this study to describe the strong relationship between teacher creativity as the dependent variable with the visionary leadership of the principal and teacher satisfaction as an independent variable. The population in this study were all permanent teachers of foundation Private Vocational High Schools in Parungkuda Sukabumi District. Samples were taken using a proportional random sampling technique totaling 96 teachers. The data analysis technique of the research results consisted of the first, statistical description and the second by using inferential statistics to test the hypothesis. The results showed that: (1) there was a very significant positive relationship between Principal Visionary Leadership and Teacher Creativity with a simple linear regression equation $\hat{Y}=89.33+0.32 \mathrm{X} 1$ and the correlation coefficient value ry. $1=0.217$. The coefficient of determination $\mathrm{r} 2 \mathrm{y} .1=0.217$ means that the Visionary Leadership of the Principal (X1) contributes to the teacher's creativity by $16.50 \%$; (2) there is a very significant positive relationship between Job Satisfaction with teacher creativity with a simple linear regression equation $\hat{Y}=88.48+0.31 \mathrm{X} 2$ and the correlation coefficient ry. $2=0.319$, and the coefficient of determination r2y.2 $=0.122$ which means that the contribution of Job Satisfaction (X2) to the creativity of teachers is $20.46 \%$. (3) there is a very significant positive relationship between Principal Visionary Leadership and Job Satisfaction together with teacher creativity with multiple linear regression equations $88=77.25+0.21 \mathrm{X} 1+0.12 \mathrm{X} 2$ and the value of the correlation coefficient ry. 12 $=0.165$. The coefficient of determination r2y.12 $=0.390$ means that the Visionary Leadership of the Principal (X1) and Job Satisfaction (X2) jointly contribute to the teacher's Creativity (Y) of $21.70 \%$.
\end{abstract}

Keywords: visionaryleadership; job satisfaction; teacher creativity

\section{INTRODUCTION}

The implementation of the 2013 curriculum has begun to be implemented in several target schools spread across almost all provinces in Indonesia starting in the 2013 school year. Thematic learning models are one of them, and the one most affected by this change is the teacher because the teacher is the central holder of the teaching and learning process in the classroom. Creative teachers become the main needs in the implementation of the 2013 curriculum. In its implementation, teachers must have a variety of concepts and ways to boost the quality of learning by providing a conducive environment, a democratic learning climate, involving students optimally in learning both physically, socially, and emotionally. Often teachers are afraid of the word creativity, it is because they assume that they do not have a creative soul. They are of the view that creativity is a skill given from birth and only for some people.

In the $21 \mathrm{st}$ century where communication, collaboration, critical thinking, and problem-solving skills need to be mastered by students, teachers are required to be more creative in providing classroom material. All education experts agree that education should ideally not merely transfer knowledge from teachers to students. More than that, education should inspire to bring out the creativity and innovation of students[1].

Teachers who have creative abilities are important aspects that must be possessed if they are expected to create a learning environment that encourages and further expects students to be creative. Progress in the world of education requires a high level of creative ability from teachers. In addition to the important role of the visionary principal, supervision is also needed from the principal in the implementation of learning in schools. There are some other factors that must be considered in increasing teacher creativity, namely; 1) the use of varied learning methods, 2) opening to new things, 3 ) believing in their abilities and rich initiatives, 4) having a sense of responsibility, 5) requiring to be able to make systematic work planning.

From the statement above, it can be concluded that the level of creativity of Private Vocational High School teachers in Parungkuda Sukabumi Subdistrict is still relatively low, this is thought to be related to the visionary leadership of the principal who is still lacking in support, so that it does not support the improvement of teacher creativity, the emergence of low teacher creativity is thought to have a relationship with job satisfaction.

The job satisfaction factor is an individual thing because each individual will have a different level of satisfaction following the values that apply in each individual. The more aspects of the work that are following individual desires, the higher the level of satisfaction felt. This attitude in the world of educational organizations is reflected in work morals, discipline and work performance.

The purpose of this study is to examine the improvement of teacher creativity which is driven by the 
visionary leadership strength of the principal and job satisfaction of teachers. It is suspected that there is a link between the three variables mentioned above.

Creativity is an attempt to involve or combine ideas or ideas from individuals or groups in new ways. Creative thinking reaches thoughts that go beyond what is known in the habits of ordinary people [2]. Creativity is the ability to make new combinations, based on existing data, information, or elements. In this case, it can mean that creativity does not need to create new things, but it is a combination of things that already exist. [3]. Creativity is emotional intelligence related to tenacity, patience, and fortitude in dealing with uncertainties and various problems related to activities that produce creative [4]. Creativity is defined as the ability to create something new and the ability to make new combinations, based on data, information, or elements that already exist or are known before, that is all the experiences and knowledge that a person has gained during his life in the school, family environment, and from the community[5]. Visionary leadership involves the ability, capability, extraordinary expertise to offer success and triumph in the future. A visionary leader is able to anticipate events that might arise, manage the future and encourage others to act in the right ways. That means, visionary leaders are able to see the challenges and opportunities before they occur and then set the organization to achieve its best goals [6]. Visionary leaders are leaders who can build a 'new dawn' (working with new dawn) with intuition and imagination, appreciation, and boldness [7]. The principal's visionary leadership indicators include: (1) creating a vision into action, (2) thinking of the future (3) motivating inspiration, (4) intellectual encouragement and (5) personal attention and (6) communicating well.

Job satisfaction is a pleasant emotional state that results from the assessment of one's work or work experience [8]. Job satisfaction is a collection of feelings and beliefs that people have about their current work. Satisfaction at work can affect the performance of a person. Job satisfaction is a positive feeling about a job and work arrangements. The attitude and feeling of pleasure or failure of a teacher in carrying out a job [9]. Job satisfaction is one's evaluation of work and works context by involving different feelings of satisfaction according to the values that apply in each individual. [10]. Job satisfaction is an affective or emotional response to a variety of one's work.

Through pleasant emotional attitudes and loving work [11]. Job satisfaction is usually defined as the degree of positive influence on the job or work situation. Individuals will have different levels of satisfaction according to the values that apply in each individual [12]. Job satisfaction is defined as a pleasant or positive emotional state that results from the assessment of one's work [13]. The more aspects of work that are following individual desires, the higher the level of satisfaction felt, and encourage achieving excellence in work. Indicators for job satisfaction variables are: 1) own work, 2) salary giving, 3) towards promotions, 4) against superiors, and 5) towards co- workers.

\section{RESEARCH METHODS}

The research method used is the survey method and the correlational approach, which is the type of research that seeks to indicate whether there is a relationship between the independent variable and the dependent variable. This study uses a quantitative approach because of the accuracy, perseverance and critical attitude of the research data in the form of figures that must be processed statistically so that it is easy to generalize. There are two independent variables in this study, namely: visionary leadership of the principal (X1) and job satisfaction (X2), while the dependent variable is the creativity of the teacher $(\mathrm{Y})$.

The constellation of problems in research is illustrated in the form of a chart as follows:

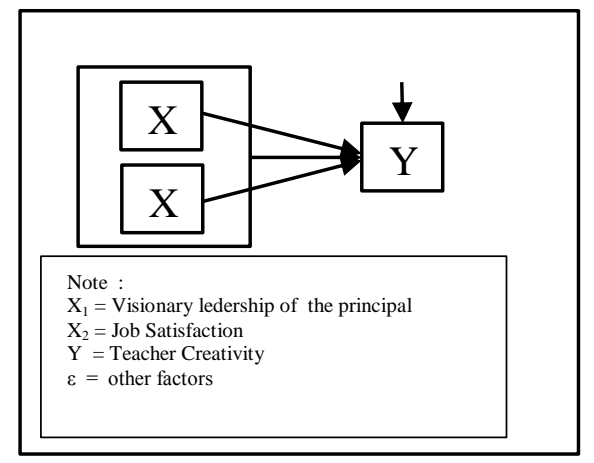

Figure 1. The constellation of problems in research

The population in this study were all permanent teachers of foundation Private Vocational High Schools in Parungkuda Sukabumi District. The sample is carried out using the Proportional Random Sampling technique, with a sample size of 96 .

Data collection in this study used research instruments, which included the teacher's creativity instrument, the principal's visionary leadership instrument and the instrument of job satisfaction. The data analysis technique of the research results consisted of statistical description and inferential statistics to test the hypothesis.

\section{RESULTS AND DISCUSSION}

After having data collection, herewith a data description of the research:

Tabel 1. Statistical description of variables $\mathrm{Y}, \mathrm{X}_{1}$ and $\mathrm{X}_{2}$

\begin{tabular}{|l|l|c|c|c|}
\hline No. & Datadescrintion Type & Y & X1 & X2 \\
\hline 1. & Lowest S & 101 & 91 & 105 \\
\hline 2. & Highest Score & 140 & 138 & 144 \\
\hline 3. & Total Score & 13047 & 11741 & 12672 \\
\hline 4. & Standard Deviation & 127 & 114 & 123 \\
\hline 5. & Median & 8,7 & 11,1 & 9,8 \\
\hline 6. & Modus & 143,5 & 115 & 122 \\
\hline 7. & Range & 142 & 115 & 122 \\
\hline 8. & Variance & 39 & 47 & 39 \\
\hline
\end{tabular}




\section{Testing Requirements Analysis}

\section{Normality Test}

a. Estimation Error Normality Test (Y-Ŷ1) Regression Equation of Teacher Creativity (Y) Variables on Visionary Leadership (X1): $\hat{Y}=99.53+0.32 X 1$

The requirement for estimating the error in a normal distribution is if the Lcount value <Ltable, Thus, the estimated error (Y-Ŷ1) regression equation for the Teacher Creativity teacher (Y) for Visionary Leadership $(\mathrm{X} 1)$ is normally distributed $($ Lcount $=0.081<0.083=\mathrm{L}$ table).

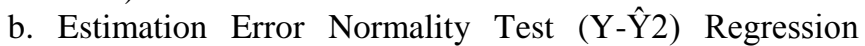
Equation of Teacher Creativity (Y) for Job Satisfaction $(\mathrm{X} 2): \hat{\mathrm{Y}}=91.09+0.37 \mathrm{X} 2$.

The requirement for estimating the error in a normal distribution is if the Lcount value < Ltable, Thus, the estimated error $(\mathrm{Y}-\hat{\mathrm{Y}} 2)$ regression equation variable of Teacher Creativity (Y) on Job Satisfaction (X2) is normally distributed $($ Lcount $=0.080<0.083=\mathrm{L}$ table). A summary of the normality test using the Lilieffors test can be seen in table 2.

Tabel 2. Summary of the normality error test estimates of Y-Y1 and Y-Y2

\begin{tabular}{|c|c|c|c|c|}
\hline No & Estimated & Lcount & $\begin{array}{l}\text { Ltable } \\
(0,05 ; 103)\end{array}$ & Conclusion \\
\hline 1 & $\mathrm{Y}-\hat{\mathrm{Y}} 1$ & 0,081 & 0,083 & Normal \\
\hline 2 & $\mathrm{Y}-\hat{\mathrm{Y}} 2$ & 0,080 & 0,083 & Normal \\
\hline
\end{tabular}

\section{Homogeneity Test}

a. Homogeneity Test Variance Score Teacher Creativity (Y) based on Visionary Leadership Scores (X1).

Homogeneous variance requirements are if Lcount arithmetic $<\chi$ 2table. Thus, the variance of Teacher Crativity or teacher score (Y) based on the Visionary Leadership score (X1) comes from a homogeneous population $($ Lcount $=19.73<50.99=\chi 2$ table $)$.

b. Homogeneity Test Variance Score Teacher Creativity (Y) based on Job Satisfaction Score (X2)

Homogeneous variance requirements are if Lcount arithmetic $<\chi 2$ table. Thus, the variance of Teacher Creativity score (Y) based on Job Satisfaction score (X2) comes from a homogeneous population $($ Lcount $=24.45$ $<49.80=\chi 2$ table) .

Summary of the homogeneity test of the variance of Teacher score (Y) based on Visionary Leadership score (X1) and Job Satisfaction score (X2) using the Bartlett test can be seen in table 3.

\section{Hypothesis test}

1. Relationship between Teacher Creativity and Visionary Leadership

The relationship between Teacher Creativity and Visionary Leadership is explained by testing the statistical hypothesis stated as follows:
H0: py $1=0$ There is no relationship between Teacher Creativity and Visionary Leadership.

H1: py1>0 There is a positive relationship between Teacher Creativity and Visionary Leadership.

Tabel 3. Summary of the Variance Homogeneity Test

\begin{tabular}{|c|c|c|c|c|}
\hline No. & Grouping & $\chi_{\text {count }}^{2}$ & $\begin{array}{c}\chi_{\text {table } \alpha}^{2}(\alpha= \\
0,05)\end{array}$ & Conclusion \\
\hline 1. & $\begin{array}{c}\text { Y on the } \\
\text { basis of } \\
\mathrm{X}_{1}\end{array}$ & 21,43 & 52,99 & $\begin{array}{c}\text { Homogeneous } \\
\text { Population }\end{array}$ \\
\hline 2. & $\begin{array}{c}\text { Yon the } \\
\text { basis of } \\
\mathrm{X}_{2}\end{array}$ & 25,45 & 50,80 & $\begin{array}{c}\text { Homogeneous } \\
\text { Population }\end{array}$ \\
\hline \multicolumn{4}{|c|}{ Homogeneous population requirements: ${ }_{\chi^{2 c o u n t}}<\chi_{\text {table }}^{2}$} \\
\hline
\end{tabular}

2. The Relationship Between Job Satisfaction and Teacher Creativity

The relationship between Teacher Creativity is explained by testing the statistical hypotheses stated as follows:

H0: py $2=0$ There is no relationship between the Teacher Creativity with Job Satisfaction

H1: py2> 0 There is a positive relationship between Teacher Creativity and Job Satisfaction.

3. Analysis of the Relationship between Visionary Leadership (X1) and Job Satisfaction (X2) together with Teacher (Y). The result of the correlation test can be shown on table 4.

Tabel 4. Results of Calculation of Significance Tests for Correlation of Visionary Leadership and Job Satisfaction Together with Teacheror

\begin{tabular}{|c|c|c|c|c|c|}
\hline \multirow{2}{*}{$\begin{array}{c}\text { Correlation } \\
\text { Coefficient ry.12 }\end{array}$} & \multirow{2}{*}{$\mathrm{dk}$ numerator } & \multirow{2}{*}{$\begin{array}{c}\mathrm{dk} \\
\text { denominator }\end{array}$} & \multirow{2}{*}{$F_{\text {oxut }}$} & Ftable & \multirow{2}{*}{ Conclusion } \\
\hline & & & & $\boldsymbol{\alpha}=0,05$ & \\
\hline 0,390 & 3 & 105 & 23,43 & 4,09 & $\begin{array}{c}\text { Very } \\
\text { Significant }\end{array}$ \\
\hline \multicolumn{6}{|c|}{$\begin{array}{l}\text { Significance level test requirements: } \\
\qquad F_{\text {seent }}>F_{\text {taple }}\end{array}$} \\
\hline
\end{tabular}

\section{Partial Correlation Test}

The results of the calculation of the partial correlation coefficient and the partial correlation significance test can be seen in Table 5.

Table 5. Calculation Result of Partial Correlation Significance Tests

\begin{tabular}{|c|c|c|c|c|}
\hline \multirow{2}{*}{ Variable control } & \multirow{2}{*}{ Inartial } & \multirow{2}{*}{$F_{\text {count }}$} & trable & \multirow{2}{*}{ Conclusion } \\
\hline & & & $\alpha=0,05$ & \\
\hline $\mathrm{X}_{2}$ & 0,390 & 3,57 & 1,96 & Very Significant \\
\hline $\mathrm{x}_{1}$ & 0,401 & 3,34 & 1,96 & Very Significant \\
\hline
\end{tabular}


1. Relationship Between the Visionary Leadership (X1) with Teacher Creativity (Y).

The results showed that there was a positive relationship between Visionary Leadership and Teacher Creativity. This is indicated by the correlation coefficient (ry.1) of 0.417 which is stated to be very significant. The contribution of the Visionary Leadership to Teacher Creativity is $16.50 \%$ which is stated by the coefficient of determination (r2y.1) of 0.174 . The partial correlation coefficient of Visionary Leadership (with controlled Job Satisfaction variables) was 0.417 which was stated to be very significant.

Based on a simple linear regression equation $\hat{Y}=$ $99.53+0.32 \mathrm{X} 1$, it is predicted that every increase of one Visionary Leadership score will cause an increase of 0.34 Teacher Creativity score to a constant of 99.53. The results of this study conclude that Visionary Leadership owned positively contributes which significantly affects Teacher Creativity.

The findings from other researches prove that the teacher creativity and there is an interaction effect between the teaching method and natural intelligence in relation to environmental view of the student's behavior [14]. It is said that not only visionary leadership has a positive and significant relationship with innovativeness, but transformational leadership has the same relationship [15].

In essence the Visionary Leadership is the leadership that can respond and change employee attitudes to commit to supporting the organization's vision, mission, and goals, as measured by instruments in the indicators, including: (1) creating a vision into action, (2) thinking of the future (3) motivating inspiration, (4) intellectual encouragement and (5) personal attention and (6) communicating well.

The principal as a person who is given the task to lead the school is responsible for achieving the goals, roles, and quality of education in the school. One indicator of visionary leadership is that leaders can develop subordinate Teacher Creativity by creating a comfortable work environment.

Visionary leadership that creates a comfortable work atmosphere can encourage interaction among teachers. With this interaction, teachers can conceal their inspiration and encouragement to make something new and innovative.

2. The Relationship Between Job Satisfaction (X2) and Teacher Creativity (Y)

The results showed that there was a positive relationship between Job Satisfaction with Teacher Creativity This is indicated by the correlation coefficient (ry.2) of 0.349 which is declared significant. The contribution of Job Satisfaction to Teacher Creativity is $20.46 \%$ which is expressed by the coefficient of determination (r2y.2) of 0.116. The partial correlation coefficient of Teacher Creativity (with controlled Visionary Leadership variables) is 0.349 which is stated to be significant at $\alpha=0.05$.

The pattern of the relationship between the variable of Job Satisfaction with the variable of Teacher Creativity is expressed by a simple linear regression equation $\hat{Y}=100.44$ $+0.29 \mathrm{X} 2$.

It is predicted that each increase in one score of Job Satisfaction will cause an increase of 0.29 score in the Teacher Creativity at constant 100, 44. The existence of a positive relationship between Job Satisfaction with Teacher Creativity shows that the role of Job Satisfaction will greatly help the achievement of Teacher Creativity So, the leadership style proved to have an indirect effect on job satisfaction. In other words, the more optimal the leadership style and organizational culture, the more job satisfaction increase [16]. Job satisfaction is a collection of feelings and beliefs that people have about their current work. The indicators are: 1) own work, 2) salary giving, 3) towards promotions, 4) against superiors, and 5) towards co- workers.

3. The Relationship Between Visionary Leadership (X1) and Job Satisfaction (X2) Together with Teacher Creativity (Y)

The results showed that there was a positive relationship between Visionary Leadership and Job Satisfaction together with Teacher Creativity. This is indicated by the correlation coefficient (ry.12) of 0.390 which was stated to be very significant after being tested with the test F. Contribution of Visionary Leadership and Job Satisfaction together to Teacher Creativity of $21.70 \%$ which is expressed by the coefficient of determination ( r2y.12) of 0.152 .

The pattern of the relationship between the Visionary Leadership variables and Job Satisfaction together with the Teacher Creativity variable is shown by the multiple linear regression equation $\hat{Y}=\mathrm{X} 2$ with the regression coefficient which is stated to be very significant.

Teacher Creativity is Creativity is an attempt to involve or combine ideas or ideas from individuals or groups in new ways. The indicators of teacher work performance are as follows: (1) changes in ways, (2) realization of new ideas, (3) modification of learning aids, (4) development of learning models, (5) implementation of changes. 6) Pleasure through experiments, 7 ) Dare to take risks and not afraid to fail and 8) emotional intelligence.

\section{CONCLUSION}

The results of testing the hypothesis and the discussion described in the previous chapters can be concluded that efforts have been found to improve indicators of research variables that have a relationship with Teacher Creativity. The relationship between research variables can be explained as follows:

There is a positive and very significant relationship between Visionary Leadership (X1) and Teacher Creativity (Y) which shows that Visionary Leadership (X1) is contributing moderately to the Teacher Creativity by $16.50 \%$.

There is a positive and very significant relationship between the variable Job Satisfaction (X2) with the variable Teacher Creativity (Y) shows that Job Satisfaction (X2) 
gives a moderate contribution to Teacher Creativity is $20.46 \%$

There is a positive and very significant relationship between Visionary Leadership (X1) and Job Satisfaction variable (X2) together with Teacher Creativity (Y) indicated by a moderate contribution to Teacher Creativity (Y) of $21.70 \%$.

Teacher creativity can be achieved if the visionary leader allows the teacher to be creative and the teacher feels satisfied with the work he is doing. The interaction between these three variables is very strong and results in a significant increase in teacher creativity.

\section{Acknowledgment}

This Magister Thesis Research was carried out with Grant Funds from the Directorate of Community Service Research, Directorate General of Research and Development Strengthening of the Ministry of Research and Technology in accordance with the implementation year 2019 based on Funding Agreement between L2Dikti4 Office and Pakuan University Number: 110 / SP2H / LT / DRPM / 2019 March 8,2019 . Thus we thank the Kemenristekdikti for funding.

\section{REFERENCES}

[1] Media Indonesia. 2016. https://ebooks.gramedia. com /id/ koran/media-indonesia/20-apr-2016

[2] Luthans, Fred, Brett C. Luthans, Kyle W. Luthans, 2011. Organizational Behavior: An Evidence Based Approach, 13th Ed,

[3] Utami Munandar. 2002. Anak Unggul Berotak Prima. Jakarta: PT. Gramedia.

[4] Jamaris, M, 2013, Orientasi baru dalam Psikolog Pendidikan. Bogor : Ghalia Indonesia

[5] Ngalimun, dkk. 2013. Perkembangan dan Pengembangan Kreativitas. Yogyakarta: Aswaja Pressindo.

[6] Diyah Yuli Sugiarti, 2017 Improvement Of Visionary Leadership For The Headmasters Of Private Madrasah Aliyah, Proceeding International Conference On Islamic Education. Icied Volume: 2.

[7] Diyah Yuli Sugiarti, 2017. Improvement Of Visionary Leadership For The Headmasters Of Private Madrasah Aliyah, Proceeding International Conference On Islamic Education. ICIED. Volume: 2.

[8] Colquitt, Jasson., Jeffery A. Lepine \& Michael J. Wesson, 2015. Organization Behavior. Mc Graw Hill.

[9] Schermerhorn, R. John., James G. Hunt, Richard N. Osborn, dan Mary Uhl-Blen, 2010. Organizational Behavior. USA: John Wiley \& Sons,.

[10] McShane, Steven., and Mary ann Von Glinow, 2008. Organizational Behavior. New York: McGraw-Hill,

[11] Kinicki, Angelo., and Robert Kreitner, 2008. Organizational Behaviour. New York: McGraw-Hill,
[12] M. Jex, Steve., 2002. Organizational Psychology: A Scientist-Practitioner Approach. New York: John Wiley \& Sons,.

[13] Collin, P. Silverthorne. 2005, Organizational Psychology: In Cross-Cultural Perspective. New York: University Press,

[14] Rita Retnowati1, Henny Suharyati, et al, 2018. The Effect of Environmental Teaching Method and The Level of Natural Intelligence on The Environmental View of The Students Behavior, IOP Conf. Series: Journal of Physics: Conf. Series 1114 (2018) 012104.

[15] Henny Suharyati, Thamrin Abdullah , Bibin Rubini, Relationship between Organizational Culture, Transformational Leadership, Working Motivation to Teacher's Innovativeness, International Journal of Managerial Studies and Research (IJMSR) Volume 4, Issue 3, March 2016, PP 29-34,

[16] Henny Suharyati, Sutji Harijanto. 2018., Leadership Style of Principal and Organizational Culture Improve Teacher Job Satisfaction, Advances in Social Science, Education and Humanities Research, volume 306, International Symposium on Social Sciences, Education, and Humanities (ISSEH 2018). 